\title{
Warunki wyrażenia zgody na użycie plików typu cookies
}

\author{
Wyrok Trybunału Sprawiedliwości Unii Europejskiej \\ z dnia 1 października 2019 r. w sprawie C-673/17 \\ Bundesverband der Verbraucherzentralen und Verbraucherverbände - \\ Verbraucherzentrale Bundesverband eV przeciwko Planet $49 \mathrm{GmbH}$
}

1. Artykuł 2 lit. $f \mathrm{i}$ art. 5 ust. 3 dyrektywy 2002/58/WE Parlamentu Europejskiego i Rady z dnia 12 lipca 2002 r., dotyczącej przetwarzania danych osobowych i ochrony prywatności w sektorze łączności elektronicznej (dyrektywy o prywatności i łączności elektronicznej), zmienionej dyrektywą 2009/136/WE Parlamentu Europejskiego i Rady z dnia 25 listopada 2009 r., w związku z art. 2 lit. h dyrektywy 95/46/WE Parlamentu Europejskiego i Rady z dnia 24 października 1995 r. w sprawie ochrony osób fizycznych w zakresie przetwarzania danych osobowych i swobodnego przepływu tych danych, a także z art. 4 pkt 11 i art. 6 ust. 1 lit. a rozporządzenia Parlamentu Europejskiego i Rady (UE) 2016/679 z dnia 27 kwietnia 2016 r. w sprawie ochrony osób fizycznych w związku z przetwarzaniem danych osobowych $\mathrm{i} w$ sprawie swobodnego przepływu takich danych oraz uchylenia dyrektywy 95/46/WE (ogólnego rozporządzenia o ochronie danych), należy interpretować $w$ ten sposób, że zgoda, o której mowa w tych przepisach, nie jest ważna, jeżeli przechowywanie informacji lub dostęp do informacji już przechowywanych w urządzeniu końcowym użytkownika strony internetowej, za pośrednictwem plików cookies, zostały zaakceptowane za pomocą domyślnie zaznaczonego okienka (pola) wyboru, którego zaznaczenie użytkownik ten musi usunąć, aby odmówić udzielenia zgody.

2. Sposób interpretowania art. 2 lit. f i art. 5 ust. 3 dyrektywy 2002/58, zmienionej dyrektywą 2009/136, w związku z art. 2 lit. h dyrektywy 95/46, a także z art. 4 pkt 11 i art. 6 ust. 1 lit. a rozporządzenia 2016/679, nie powinien być różny w zależności od tego, czy informacje przechowywane lub udostępniane w urządzeniu końcowym użytkownika strony internetowej stanowią dane osobowe w rozumieniu dyrektywy 95/46 i rozporządzenia 2016/679.

3. Artykuł 5 ust. 3 dyrektywy 2002/58, zmienionej dyrektywą 2009/136 należy interpretować $w$ ten sposób, że informacje, jakich usługodawca powinien udzielić użytkownikowi strony internetowej, obejmują również wskazanie okresu funkcjonowania plików cookies oraz określenie, czy osoby trzecie mogą uzyskać dostęp do takich plików. 


\section{Michał Miłosz}

Uniwersytet Gdański

michal.milosz@ug.edu.pl

ORCID: 0000-0001-5633-9941

https://doi.org/10.26881/gsp.2021.4.09

Komentowane orzeczenie stanowi pierwszą wypowiedź Trybunału Sprawiedliwości UE (TSUE) w kwestii warunków wyrażenia zgody na użycie plików typu "cookies” w urządzeniach końcowych użytkowników, której wymóg uzyskania wynika w prawie unijnym z art. 5 ust. 3 dyrektywy o prywatności i łączności elektronicznej ${ }^{1}$, uwzględniające przepisy ogólnego rozporządzenia o ochronie danych².

Tezy wyrażone w glosowanym wyroku TSUE wyznaczają kierunek wykładni przepisów znajdujących zastosowanie przy instalowaniu plików cookies, i tym samym powinny oddziaływać na praktykę pozyskiwania zgód użytkowników na wykorzystywanie tego typu technologii. W przyszłości na tę praktykę istotny wpływ będzie miało również uchwalenie, a następnie wejście w życie procedowanego obecnie projektu rozporządzenia Parlamentu Europejskiego i Rady w sprawie poszanowania życia prywatnego i ochrony danych osobowych w łączności elektronicznej oraz uchylającego dyrektywę 2002/58/WE (rozporządzenie o prywatności i łączności elektronicznej) ${ }^{3}$, które zawierać będzie rozbudowaną regulację dotyczącą korzystania z możliwości urządzeń końcowych użytkowników do przetwarzania i przechowywania oraz gromadzenie informacji z tych urządzeń obejmującą również stosowanie plików cookies.

Komentowany wyrok TSUE został wydany w następującym stanie faktycznym. Niemiecka spółka Planet49 zorganizowała w 2013 r. loterię promocyjną. Na stronie internetowej, poprzez którą organizowana była loteria, osoby w niej uczestniczące podawały informacje osobowe, takie jak kod pocztowy oraz imię i adres. Na stronie loterii zamieszczone były teksty dwóch oświadczeń dotyczących wyrażenia określonych zgód przez użytkowników loterii. Obok oświadczeń umieszczone były pola wyboru (tzw. „okienka”). Udział w loterii był możliwy jedynie w razie zaznaczenia przynajmniej pierwszego z tych pól. Drugie pole wyboru było domyślnie zaznaczone, zatem

1 Dyrektywa 2002/58/WE Parlamentu Europejskiego i Rady z dnia 12 lipca 2002 r. dotycząca przetwarzania danych osobowych i ochrony prywatności w sektorze łączności elektronicznej (dyrektywa o prywatności i łączności elektronicznej) (Dz. Urz. UE L 201 z 2002 r., s. 37 ze zm.; dalej: dyrektywa 2002/58; dyrektywa o e-prywatności).

2 Rozporządzenie Parlamentu Europejskiego i Rady (UE) 2016/679 z dnia 27 kwietnia 2016 r. w sprawie ochrony osób fizycznych w związku z przetwarzaniem danych osobowych i w sprawie swobodnego przepływu takich danych oraz uchylenia dyrektywy 95/46/WE (ogólne rozporządzenie o ochronie danych) (Dz. Urz. UE L 119, s. 1; dalej: rozporządzenie 2016/679; ogólne rozporządzenie o ochronie danych).

3 Zob. projekt rozporządzenia Parlamentu Europejskiego i Rady w sprawie poszanowania życia prywatnego oraz ochrony danych osobowych w łączności elektronicznej i uchylające dyrektywę 2002/58/ WE (rozporządzenie w sprawie prywatności i łączności elektronicznej) w wersji przyjętej przez Komitet Stałych Przedstawicieli w dniu 10 lutego 2021 r.; dalej: projekt rozporządzenia o e-prywatności, https://data.consilium.europa.eu/doc/document/ST-6087-2021-INIT/en/pdf [dostęp: 10.11.2021]. 
użytkownik musiał usunąć to zaznaczenie w celu niewyrażenia zgody, która w przeciwnym razie zostałaby automatycznie odnotowana.

Pierwsze pole wyboru służyło do wyrażenia zgody na kontakt marketingowy z uczestnikiem loterii ze strony partnerów reklamowych jej organizatora. Zgoda ta nie dotyczyła wykorzystywania plików cookies, lecz była zgodą na realizację celów marketingowych. Kwestia skuteczności udzielenia tej zgody marketingowej nie była przedmiotem rozważań TSUE, stąd też nie będzie analizowana - jako wykraczająca poza zakres zagadnień, których dotyczy niniejsza glosa.

Drugie oświadczenie zawarte na stronie loterii odnosiło się do monitorowania zachowania uczestników na witrynach internetowych partnerów reklamowych Planet49, co wiązało się z instalowaniem plików cookies. Oświadczenie przy drugim polu wyboru brzmiało: „Wyrażam zgodę na stosowanie wobec mnie usługi analizy internetowej Remintrex. Skutkuje to tym, że organizator loterii promocyjnej [Planet49] po zarejestrowaniu uczestnika w loterii instaluje pliki cookies. Umożliwi to Planet49 ocenę mojego zachowania w zakresie odwiedzania i korzystania ze stron internetowych partnerów reklamowych i dopasowanie reklam do moich preferencji przez Remintrex. Pliki cookies mogę usunąć w dowolnym czasie. Więcej na ten temat przeczytacie Państwo tutaj". Zasadniczo informacje dostarczone przez pliki cookies miały umożliwiać Planet49 wysyłanie e-maili reklamowych uwzględniających zainteresowania ujawnione na stronach internetowych partnerów reklamowych tej spółki. W plikach tych zapisywany był numer identyfikacyjny, który w powiązaniu z danymi wpisywanymi przez zapisującego się na loterię użytkownika, powodował, że zawarte w plikach cookies informacje stanowiły dane osobowe, które z plików cookies nie były przekazywane poszczególnym partnerom reklamowym Planet49. Użytkownicy informowani byli także o możliwości usunięcia w dowolnym momencie plików ze swojej przeglądarki internetowej, a także o możliwości cofnięcia w dowolnym momencie udzielonej zgody.

Związek organizacji konsumenckich zakwestionował - na drodze sądowej - praktykę pozyskiwania zgód zastosowaną przez Planet49. Na dalszym etapie postępowania w przedmiotowej sprawie niemiecki Federalny Trybunał Sprawiedliwości (FTS) uznał, że wynik postępowania głównego zależy od wykładni art. 5 ust. 3 i art. 2 lit. $f$ dyrektywy 2002/58, art. 2 lit. h dyrektywy 95/464, jak też art. 6 ust. 1 lit. a rozporządzenia 2016/679. Mając wątpliwości dotyczące stosowania wskazanych przepisów prawa unijnego, FTS zwrócił się do TSUE z pytaniami prejudycjalnymi dotyczącymi skuteczności wyrażenia zgody na wykorzystanie plików cookies poprzez domyślnie zaznaczone pole wyboru, wpływu na stosowanie art. 5 ust. 3 i art. 2 lit. f dyrektywy 2002/58 faktu, że przechowywane lub udostępniane informacje są danymi osobowymi, a także zakresu obowiązków informacyjnych, wynikających z art. 5 ust. 3 dyrektywy 2002/58.

Wykorzystywanie plików cookies w urządzeniach końcowych użytkowników reguluje w prawie unijnym art. 5 ust. 3 dyrektywy 2002/58, w myśl którego: „Państwa

\footnotetext{
4 Dyrektywa 95/46/WE Parlamentu Europejskiego i Rady z dnia 24 października 1995 r. w sprawie ochrony osób fizycznych w zakresie przetwarzania danych osobowych oraz swobodnego przepływu tych danych (Dz. Urz. UE L 281, s. 31 ze zm.; dalej: dyrektywa 95/46).
} 
członkowskie zapewniają, aby przechowywanie informacji lub uzyskanie dostępu do informacji już przechowywanych w urządzeniu końcowym abonenta lub użytkownika było dozwolone wyłącznie pod warunkiem, że dany abonent lub użytkownik wyraził zgodę zgodnie z dyrektywą 95/46 po otrzymaniu jasnych i wyczerpujących informacji, między innymi o celach przetwarzania. Nie stanowi to przeszkody dla każdego technicznego przechowywania danych ani dostępu do nich jedynie w celu wykonania transmisji komunikatu za pośrednictwem sieci łączności elektronicznej, lub gdy jest to ściśle niezbędne w celu świadczenia usługi przez dostawcę usługi społeczeństwa informacyjnego, wyraźnie zażądanej przez abonenta lub użytkownika". Obowiązujące obecnie rozwiązanie oznacza przyjęcie tzw. mechanizmu opt-in, w którym użytkownik musi co do zasady wyrazić zgodę na wykorzystywane plików cookies przed rozpoczęciem ich stosowania. Wymóg uzyskania zgody nie ma jednak charakteru bezwzględnego. Uzyskanie zgody nie jest konieczne, w przypadku gdy wykorzystywanie plików typu cookies jest niezbędne dla wykonania transmisji komunikatu za pośrednictwem sieci łączności elektronicznej lub w celu realizacji usługi przez dostawcę usługi społeczeństwa informacyjnego, świadczonej na żądanie abonenta lub użytkownika. Oznacza to, że zgody nie wymaga m.in. instalowanie plików cookies, które są niezbędne do zapewnienia prawidłowego funkcjonowania witryny internetowej. Wskazane w art. 5 ust. 3 dyrektywy 2002/58 wyjątki nie miały jednak zastosowania w sprawie rozpoznawanej przez TSUE 5 .

Zgodnie z art. 2 lit f dyrektywy 2002/58, zgoda użytkownika lub abonenta na potrzeby tej dyrektywy odpowiada zgodzie podmiotu danych osobowych określonej w dyrektywie 95/46/WE w sprawie ochrony osób fizycznych w zakresie przetwarzania danych osobowych oraz swobodnego przepływu tych danych. Druga z wymienionych dyrektyw została uchylona i zastąpiona ogólnym rozporządzeniem o ochronie danych, które zaczęło bezpośrednio obowiązywać we wszystkich państwach członkowskich Unii Europejskiej z dniem 25 maja 2018 r. Stosownie do art. 94 ust. 2 tego rozporządzenia, wszelkie odesłania do uchylonej przez to rozporządzenie dyrektywy 95/46 należy traktować jako odesłania do ogólnego rozporządzenia o ochronie danych.

Wniosek o wydanie orzeczenia w trybie prejudycjalnym wpłynął do TSUE jeszcze przed tą datą, jednakże trybunał uznał, że w okolicznościach sprawy, konieczne jest udzielenie odpowiedzi na przedstawione pytania prejudycjalne zarówno na podstawie dyrektywy 95/46, jak i na podstawie rozporządzenia 2016/679.

Przechodząc do problemów przedstawionych w pierwszym z pytań prejudycjalnych, wpierw należy zauważyć, że art. 5 ust. 3 dyrektywy 2002/58 dotyczy instalowania plików cookies niezależnie od tego, czy dane w nich zapisywane są danymi osobowymi.

\footnotetext{
5 Na marginesie rozważań można wspomnieć, że projekt rozporządzenia o e-prywatności zakłada rozszerzenie katalogu wyjątków od wymogu uzyskania zgody użytkownika na wykorzystywanie plików cookies, przy czym żaden z nich nie ma dotyczyć wykorzystywania danych z tych plików do celów marketingowych.
} 
Zważywszy, że wykładnia pojęcia zgody w rozumieniu dyrektywy 2002/58 powinna być dokonywana na mocy odesłania zawartego w art. 2 lit $f$ tej dyrektywy, na podstawie przepisów o ochronie danych osobowych - wcześniej art. 2 lit h dyrektywy 95/46, a obecnie art. 4 pkt 11 rozporządzenia 2016/679 - istotnym pytaniem jest, czy na interpretację przepisów o udzielaniu zgody na wykorzystywanie plików cookies ma wpływ to, czy informacje w nich przechowywane stanowią dane osobowe. Trybunał na to pytanie udzielił odpowiedzi przeczącej, podkreślając, że sposób interpretowania tych przepisów nie zmienia się ze względu na okoliczność, czy dane w plikach cookies mają charakter danych osobowych. Konkluzję taką potwierdza treść motywu 24 dyrektywy 2002/58, z której wynika, że wszelkie informacje przechowywane w urządzeniach końcowych użytkownika sieci łączności elektronicznej należą do sfery prywatnej tego użytkownika, podlegającej ochronie prawnej. Zdaniem trybunału, ochrona ta obejmuje wszystkich użytkowników niezależnie od tego, czy dane przechowywane w jego urządzeniu mogą być zakwalifikowane jako dane osobowe. Również sama konstrukcja odesłania do przepisów o ochronie danych osobowych zawarta w art. 2 lit. f dyrektywy 2002/58 nie daje podstaw do różnicowania wymogów co do wyrażenia zgody na wykorzystywanie plików cookie w zależności od tego, jaki charakter mają dane w nich zapisywane. Oznacza to, że kryteria skutecznego wyrażenia zgody na przetwarzanie danych osobowych wynikających obecnie z rozporządzenia 2016/679 stanowią jednocześnie wymogi wyrażenia zgody na użycie plików typu cookies na podstawie art. 5 ust. 3 dyrektywy 2002/58.

Na gruncie przepisów ogólnego rozporządzania o ochronie danych zgoda powinna zostać udzielona w sposób dobrowolny, konkretny, świadomy i jednoznaczny. Elementy te wynikają z definicji zgody zawartej w art. 4 pkt 11 rozporządzenia 2016/679. Zgodnie z tą definicją, zgoda na przetwarzanie danych osobowych jest okazaniem woli, którego treścią jest przyzwolenie na przetwarzanie danych, i które może być wyrażone w postaci oświadczenia lub wyraźnego działania potwierdzającego. Z motywu 32 rozporządzenia 2016/679 wynika, że zgoda powinna być wyrażona w drodze jednoznacznej, potwierdzającej czynności, która wyraża odnoszące się do określonej sytuacji dobrowolne, świadome i jednoznaczne przyzwolenie osoby, których dane dotyczą, na przetwarzanie dotyczących jej danych osobowych. Pewne dalsze wymogi co do konstrukcji zgody na przetwarzanie danych można wyprowadzić jeszcze z art. 6 ust. 1 lit a oraz art. 7 rozporządzenia $2016 / 679^{6}$. Jak się wskazuje w literaturze przedmiotu, w istotnej części definicja pojęcia danych osobowych z rozporządzenia 2016/679 powiela konstrukcję zgody - ukształtowaną przepisami dyrektywy $95 / 46^{7}$. Wskazane

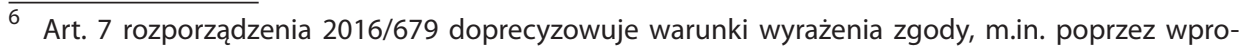
wadzenie obowiązku poinformowania o możliwości cofnięcia zgody jeszcze przed jej udzieleniem oraz wymogu, zgodnie z którym cofnięcie zgody musi być równie łatwe jak jej udzielenie. Wymogi te zarówno rzutują na zakres informacji przekazywanych użytkownikowi korzystającemu z serwisu internetowego stosującego pliki cookies, jak i mogą wpływać na dobór rozwiązań technicznych umożliwiających cofnięcie zgody na instalowanie plików cookies z danego serwisu.

7 Tak D. Lubasz [w:] idem, Komentarz do art. 4 pkt 11 [w:] RODO. Ogólne rozporzadzenie o ochronie danych. Komentarz, red. Edyta Bielak-Jomaa, Dominik Lubasz, Warszawa 2018, s. 243.
} 
powyżej kryteria ważnej zgody na przetwarzanie danych osobowych korespondują w pewnym stopniu z tymi, które są wskazane w motywie 17 dyrektywy 2002/58, zgodnie z którym zgoda użytkownika lub abonenta może być udzielona w jakikolwiek sposób umożliwiający swobodne i świadome wyrażenie woli użytkownika, włączając zaznaczenie okna wyboru podczas przeglądania witryny internetowej.

Trybunał Sprawiedliwości Unii Europejskiej uznał, że zarówno na gruncie przepisów dyrektywy 95/46, jak i rozporządzenia 2016/679 nie ma się do czynienia z ważnie udzieloną zgodą w rozumieniu art. 5 ust. 3 dyrektywy 2002/58, jeżeli przechowywanie informacji lub dostęp do informacji już przechowywanych w urządzeniu końcowym użytkownika strony internetowej został zaakceptowany za pomocą domyślnie zaznaczonego pola wyboru, którego zaznaczenie użytkownik musi usunąć, aby odmówić udzielenia zgody.

W świetle konstrukcji zgody wynikającej z przepisów o ochronie danych osobowych takie rozstrzygnięcie nie może budzić żadnych wątpliwości. Zarówno z wcześniejszych, jak i obecnie obowiązujących przepisów regulujących sposób wyrażenia zgody na przetwarzanie danych osobowych należy wywieść, że zgoda ta musi być wyrażona w sposób czynny ${ }^{8}$. W motywie 32 ogólnego rozporządzenia o ochronie danych wyjaśniono, że wyrażenie zgody może polegać m.in. na zaznaczeniu pola wyboru podczas przeglądania strony internetowej, jednocześnie motyw ten wyklucza możliwość wyrażenia zgody poprzez „milczenie, okienka domyślnie zaznaczone lub niepodjęcie działania". Zatem brak aktywności użytkownika strony internetowej polegający na nieodznaczeniu domyślnie zaznaczonego pola wyboru nie może być uznawany za skuteczne wyrażenie zgody ${ }^{9}$. Nie można bowiem przyjmować, że skoro dany podmiot nie odznaczył określonego pola wyboru na stronie internetowej, to w sposób wyraźny, jednoznaczny i świadomy wyraził zgodę na wykorzystywanie plików cookies przez dany serwis internetowy. Takiej oceny nie zmienia fakt, że aby kontynuować, użytkownik musiał jeszcze kliknąć link zapisujący go na loterię. Wymóg jednoznaczności zgody oznacza, że jej wyrażenie nie powinno budzić wątpliwości co do zamiaru osoby, która jej udziela. Dlatego zgoda na pliki cookies nie może być wywodzona z kliknięcia linku umożliwiającego zapisanie się na loterię. Nie jest to bowiem działanie jednoznaczne, zważywszy, że użytkownik może w ogóle nie mieć świadomości, co do tego, iż w ten sposób wyraża „przy okazji” zgodę na instalowanie i dostęp do plików cookies ${ }^{10}$. Jak słusznie podkreślił trybunałł „nie można [...] wykluczyć, że wspomniany użytkownik

8 Zob. też K. Wiedemann, The ECJ's Decision in "Planet49" (Case C-673/17): A Cookie Monster or Much Ado About Nothing? "International Review of Intellectual Property and Competition" 2020, nr 51, s. 543-553, https://link.springer.com/article/10.1007/s40319-020-00927-w [dostęp: 10.11.2021].

9 Por. P. Litwiński, P. Barta, M. Kawecki, Komentarz do art. 4 [w:] Rozporządzenie UE w sprawie ochrony osób fizycznych w zwiqzku z przetwarzaniem danych osobowych i swobodnym przepływem takich danych. Komentarz, red. P. Litwiński, Warszawa 2018, s. 230.

10 Zob. też uwagi dotyczące tej kwestii, w tym odniesienia do treści art. 7 ust. 2 rozporządzenia 2016/679 poczynione przez K. Wiedemanna [w:] idem, The ECJ's Decision...; zob. ponadto R. Barcelo, A. Ibraimova, E. Yaltaghian, The Planet49 Decision: Key Takeaways, "The National Law Review” z dnia 2 października 2019 r., https://www.natlawreview.com/article/planet49-decision-key-takeaways [dostęp: 10.11.2021]. 
nie przeczytał informacji towarzyszącej domyślnie zaznaczonemu okienku czy wręcz nie zwróci uwagi na to okienko przed podjęciem dalszej aktywności na odwiedzanej przezeń stronie internetowej".

Odnotowania wymaga, że trybunał nie rozpatrywał kwestii, czy w przypadku, w którym zgoda użytkownika na przetwarzanie jego danych osobowych do celów reklamowych decyduje o tym, czy może on uczestniczyć w loterii promocyjnej, spełnia wymóg wyrażenia zgody w sposób dobrowolny, uznając, że leży to poza zakresem sprawy $^{11}$. Niewątpliwe jednak problematyka uzależniania możliwości korzystania z określonych usług od wyrażenia zgody na wykorzystanie danych osobowych w celach marketingowych jest niezwykle ważka, a ocena dopuszczalności zastosowania takiego uwarunkowania będzie stanowić kluczową kwestię w wypadkach pozyskiwania takich zgód, gdy pozostałe wymogi wyrażenia skutecznej zgody będą spełnione.

Podkreślenia wymaga, że przed podjęciem przez użytkownika działania wyrażającego zgodę na pliki cookies, żadne z tych plików, które wymagają takiej zgody, nie mogą być instalowane na urządzeniu użytkownika. Niewłaściwym działaniem serwisu internetowego jest zatem instalowanie plików cookies, zanim użytkownik będzie miał możliwość wyrażenia na nie zgody, nawet wówczas, gdy następnie są one usuwane, w razie gdy zgoda ta nie zostanie udzielona. Automatyczne instalowanie plików cookies (w tym reklamowych) zaraz po wejściu na strony internetowe google.fr oraz amazon.fr było elementem ustaleń w sprawach, w których francuski organ właściwy do spraw ochrony danych osobowych (Commission Nationale de l'Informatique et des Libertés - CNIL) w 2020 r. nałożył kary pieniężne na Google LLC i Google Ireland Limited (odpowiednio w wysokości $60 \mathrm{mln}$ i 40 mln euro) ${ }^{12}$ oraz na Amazon Europe Core (w wysokości $35 \mathrm{mln}$ euro) ${ }^{13}$. Kary te zostały nałożone za nieprzekazywanie użytkownikowi wymaganych prawem informacji w związku z posługiwaniem się cookies, a także za zapisywanie plików cookies bez uprzedniej zgody użytkowników. Dodatkowo, Google został ukarany za nierespektowanie prawa do sprzeciwu.

Wynikający z wyroku TSUE wymóg udzielania zgody w sposób aktywny wyklucza posługiwanie się na stronach internetowych banerami zgód na pliki cookies z domyślnie zaznaczonymi polami wyboru - nie dotyczy to jednak plików cookies, których używanie nie wymaga zgody. Pasywnym zachowaniem, niestanowiącym zgody, będzie także pozostanie na stronie i dalsze jej przeglądanie, nawet jeśli użytkownik został poinformowany o stosowaniu plików cookies, ale nie wyraził w żaden aktywny sposób akceptacji na ich instalowanie ${ }^{14}$. Stąd też wykluczone jest przyjęcie, że zgoda na

11 Zob. pkt 64 glosowanego wyroku.

12 Źródła: https://www.cnil.fr/en/cookies-financial-penalties-60-million-euros-against-companygoogle-llc-and-40-million-euros-google-ireland [dostęp: 10.11.2021].

13 Źródła: https://www.cnil.fr/en/cookies-financial-penalty-35-million-euros-imposed-companyamazon-europe-core [dostęp: 10.11.2021].

14 Europejska Rada Ochrony Danych w swych wytycznych wskazywała, że „w myśl motywu 32 przewijanie w dół, przeglądanie strony internetowej lub podobne działania użytkownika w żadnych okolicznościach nie spełniają wymogu wyraźnego i potwierdzającego działania: działania takie może być trudno odróżnić od innych działań lub reakcji użytkownika, a zatem niemożliwe również będzie stwierdzenie, że uzyskano jednoznaczną zgodę. Ponadto, w takim przypadku trudne będzie 
pliki cookies może być wyrażona poprzez same ustawienia przeglądarki internetowej, bez podjęcia przez użytkownika jakiejkolwiek aktywności na odwiedzanej witrynie. Użytkownik bowiem może nie tylko nie być świadomy, jakie są domyślne ustawienia preferencji dotyczące instalowania plików cookies w jego przeglądarce internetowej, ale może też nie wiedzieć, że przeglądarka umożliwia określenie takich preferencji. Nie można też wykluczyć, że użytkownik posługuje się oprogramowaniem, które w ogóle nie zawiera takiej funkcjonalności.

W kontekście korzystania z domyślnych ustawień przeglądarki internetowej w celu ustanowenia własnych preferencji co do instalowania plików cookies należy zwrócić uwagę na złożony problem możliwości wykorzystywania tego typu ustawień w razie przetwarzania danych z plików cookies w różnych celach. Złożoność tego problemu wynika także z konieczności uwzględnienia treści przepisów krajowych implementujących w danym państwie członkowskim postanowienia dyrektywy 2002/58. Opierając się na kryterium dobrowolności zgody na przetwarzanie danych osobowych, należy uznać, że w każdym przypadku, w którym dane z plików cookie są wykorzystywane w różnych celach (wymagających zgody) i jednocześnie przetwarzane dane stanowią dane osobowe operator serwisu internetowego powinien zbierać odrębne zgody na poszczególne cele ${ }^{15}$. Przykładowo, sytuacja taka ma miejsce, gdy użytkownik zalogowany jest do określonego serwisu, a dane zapisywane w plikach cookies umożliwiają jego identyfikację. Sytuacja taka miała miejsce też w sprawie, w której wydano glosowany wyrok - pliki cookies wykorzystywane przez Planet49 zawierały bowiem identyfikatory powiązane z innymi danymi konkretnego użytkownika. W przypadkach takich jak wskazane powyżej serwis nie może opierać się na jednej ogólnej zgodzie, w tym wyrażonej poprzez ustawienia przeglądarki, lecz pozyskać odrębne zgody na poszczególne cele przetwarzania, które takowej zgody wymagają ${ }^{16}$. W razie przetwarzania danych osobowych łączne wyrażenie zgody na niepowiązane cele - np. cele analityczne i cele marketingowe podmiotów trzecich - nie będzie spełniać wymogu

zapewnienie użytkownikowi możliwości wycofania zgody w sposób równie łatwy, co jej udzielenie". Zob. wytyczne 05/2020 Europejskiej Rada Ochrony Danych dotyczące zgody na mocy rozporządzenia 2016/679, wersja 1.1 przyjęta dnia 4 maja 2020 r., s. 21, https://edpb.europa.eu/sites/default/files/files/ file1/edpb_guidelines_202005_consent_pl.pdf [dostęp: 10.11.2021]; dalej: wytyczne EROD 05/2020. Por. też uwagi dotyczące czynności przeglądania strony w kontekście wymogu uzyskania zgody na wykorzystywanie plików cookies, sformułowane przez: R. Barcelo, A. Ibraimova, E. Yaltaghian, The Planet49 Decision... oraz G. Zanfir-Fortuna, Planet49 CJEU Judgment brings some 'Cookie Consent' Certainty to Planet Online Tracking, opubl. w dniu 3 października 2019 r., http://www.pdpecho.com [dostęp: 10.11.2021].

15 Uzupełniająco należy wskazać, że w przypadku przetwarzania danych z plików cookies, które mają charakter danych osobowych, w rachubę może również wchodzić wymóg uzyskania swojego rodzaju kwalifikowanej zgody na gruncie rozporządzenia o ochronie danych a mianowicie „zgody wyraźniej”. Przykładowo, wymóg uzyskania takiej zgody, w określonych w art. 22 rozporządzenia 2016/679 przypadkach, zachodzić będzie w razie podejmowania decyzji w oparciu o zautomatyzowane przetwarzanie danych, w tym w o profilowanie. Sytuacja taka może przykładowo wiązać się z wyświetlaniem w stosunku do użytkowników internetu, czyli podmiotów danych osobowych - reklam profilowanych w oparciu m.in. o dane zapisywane w plikach cookies.

16 Por. P. Litwiński, P. Barta, M. Kawecki, Komentarz do art. 6 [w:] Rozporzqdzenie..., s. 280. 
dobrowolności na gruncie rozporządzenia 2016/679. W decyzji wydanej w styczniu 2019 r. francuski organ nadzorczy CNIL nałożył na Google LLC karę w wysokości $50 \mathrm{mln}$ euro po ustaleniu w prowadzonym postępowaniu, m.in. że na prowadzonym przez Google serwisie internetowym brak jest możliwości wyrażenia oddzielnych zgód na różne cele przetwarzania ${ }^{17}$.

Zważywszy, że narzędzia dostarczane przez przeglądarki internetowe zasadniczo nie ustalają celów, w jakich instalowane są pliki cookies i w sposób precyzyjny nie pozwalają różnicować preferencji co do różnych typów takich plików, nie da się efektu uzyskania odrębnych zgód osiągnąć poprzez zaakceptowanie w danym serwisie ustawień przeglądarki internetowej użytkownika. W praktyce oznacza to, że serwis internetowy, przetwarzając dane osobowe w plikach cookies, musi stosować własne rozwiązania umożliwiające zarządzanie takimi plikami i zgodami wyrażanymi przez użytkowników serwisu.

Na gruncie prawa polskiego - art. 173 ustawy - Prawo telekomunikacyjne ${ }^{18}$, stanowiącego implementację art. 5 ust. 3 dyrektywy 2002/58 oraz art. 174 tejże ustawy ${ }^{19}$ inaczej ocenia się sytuację, w których dane z plików cookies są przetwarzane w różnych celach, lecz nie zawierają danych osobowych. Zasadniczo przyjmuje się, że wystarczające jest wówczas wyrażenie jednej ogólnej zgody na instalowanie plików cookies, w tym także poprzez odesłanie do ustawień przeglądarki. Stanowisko takie opiera się na treści art. 173 ust. 2 p.t., który przewiduje, że abonent lub użytkownik końcowy może wyrazić zgodę za pomocą ustawień oprogramowania zainstalowanego w wykorzystywanym przez niego telekomunikacyjnym urządzeniu końcowym lub za pomocą konfiguracji usługi. Jednakże stanowisko TSUE zajęte w sprawie Planet49, w myśl którego wykładnia przepisów mająca zastosowanie przy zbieraniu zgód na pliki cookies nie powinna być różnicowana ze względu na to, czy zawierają one dane osobowe, czy nie - może potencjalnie prowadzić do bardziej rygorystycznej wykładni. W zarysowanym kontekście należy zauważyć, że motyw 32 rozporządzenia 2016/679 dopuszcza możliwość wyrażenia zgody poprzez wybór ustawień technicznych do korzystania z usług społeczeństwa informacyjnego. Jednocześnie Europejska Rada Ochrony Danych wyjaśniała, że w przypadku wyrażenia zgody za pośrednictwem ustawień przeglądarki internetowej ustawienia takie powinny być opracowane zgodnie z przesłankami ważnej zgody określonymi w ogólnym rozporządzeniu o ochronie danych, takimi jak na przykład fakt, że zgoda powinna być szczegółowa dla każdego $z$ zamierzonych celów ${ }^{20}$. Szersza analiza tego problemu oraz relacji między przepisami unijnymi a przepisami krajowymi stanowiącymi implementację art. 5 ust. 3 dyrektywy 2002/58 wykracza poza zakres niniejszej glosy. Należy oczekiwać, że ostateczne

\footnotetext{
17 Źródło: https://www.cnil.fr/en/cnils-restricted-committee-imposes-financial-penalty-50-millioneuros-against-google-Ilc [dostęp: 10.11.2021].

18 Ustawa z dnia 16 lipca 2004 r. - Prawo telekomunikacyjne (tekst. jedn.: Dz. U. z 2021 r., poz. 576; dalej: p.t.).

19 Zgodnie z przywołanym art. 174 p.t., do uzyskania zgody abonenta lub użytkownika końcowego stosuje się przepisy o ochronie danych osobowych.

20 Zob. wytyczne EROD 05/2020, s. 21.
} 
rozwiązanie tego dylematu przyniesie przyjęcie rozporządzenia o e-prywatności ${ }^{21}$. Projekt tego rozporządzenia zakłada, tak jak ma to miejsce obecnie, że do zgody na wykorzystanie technologii typu cookies zastosowanie znajdą warunki zgody wynikające z rozporządzenia 2016/67922. Projekt rozporządzenia o e-prywatności przewiduje także, że zgodę tę będzie można wyrazić poprzez wykorzystanie właściwych ustawień technicznych oprogramowana umożliwiającego komunikację elektroniczną, w tym wyszukiwanie i prezentację informacji w internecie. Przy czym zawsze nadrzędna w stosunku do ustawień oprogramowania ma być zgoda wyrażona przez użytkownika w sposób bezpośredni ${ }^{23}$.

Przedmiotem rozważań TSUE w wyroku w sprawie Planet49 był również zakres informacji, jaki należy przekazać na podstawie art. 5 ust. 3 dyrektywy 2002/58 osobie wyrażającej zgodę na wykorzystywanie plików cookies, a konkretnie - kwestia, czy muszą one zawierać także informację o okresie funkcjonowania plików cookies oraz o tym, czy podmioty trzecie mogą uzyskać dostęp do tych plików.

W myśl art. 5 ust. 3 dyrektywy 2002/58, wykorzystywanie plików cookies możliwe jest pod warunkiem, że zgoda użytkownika na nie została wyrażona „po otrzymaniu jasnych i wyczerpujących informacji, między innymi o celach przetwarzania”. Zdaniem TSUE, w sytuacji, w której pliki cookies mają na celu zbieranie informacji do celów reklamowych w odniesieniu do produktów partnerów organizatora loterii promocyjnej, zarówno wskazanie okresu funkcjonowania plików cookies, jak też określenie, czy osoby trzecie mogą mieć dostęp do tych plików stanowi element jasnych i wyczerpujących informacji, które należy przekazać zgodnie z przywołanym przepisem dyrektywy $2002 / 58$. Trybunał zauważył również, że podanie informacji dotyczących okresu funkcjonowania plików cookies spełnia wymóg rzetelnego przetwarzania danych ${ }^{24}$.

Odnosząc się do stanowiska wyrażonego przez trybunał, w pierwszej kolejności należy zauważyć, że jednym z podstawowych kryteriów wyrażenia skutecznej zgody na gruncie przepisów ogólnego rozporządzenia o ochronie danych jest wyrażenie jej w sposób świadomy. Kryterium świadomości zgody wiąże się z wymogiem przekazania osobie, która ma jej udzielić, informacji niezbędnych do zrozumienia istoty tego, na co wyraża zgodę i typowych konsekwencji jej wyrażenia ${ }^{25}$. Należy uznać, że kwestia udostępniania danych pozyskiwanych na podstawie zgody podmiotom trzecim jest istotnym aspektem realizowanego celu lub celów przetwarzania danych. Konsekwentnie należy uznać, że udostępnianie danych z plików cookies podmiotom trzecim stanowi element charakterystyki celu, w jakim dane te są przetwarzane. W przypadku udostępniania danych z plików cookies podmiotom trzecim, udostępnianie to wpły-

\footnotetext{
21 Aktualnie proponowane rozwiązania zawiera art. 8 projektu rozporządzenia o e-prywatności.

22 Zob. art. 4a projektu rozporządzenia o e-prywatności.

23 Zob. art. 4 ust. 2 i 2 aa projektu rozporządzenia o e-prywatności.

24 W piśmiennictwie zauważono, że spostrzeżenie takie jest to o tyle wyjątkowe, iż trybunał w swoim orzecznictwie w zakresie ochrony danych osobowych zazwyczaj nie dokonuje ustaleń w odniesieniu do rzetelności przetwarzania - zob. G. Zanfir-Fortuna, Planet49...

25 Por. P. Fajgielski, Ogólne rozporządzenie o ochronie danych. Ustawa o ochronie danych osobowych. Komentarz, Warszawa 2018, s. 128.
} 
wa niewątpliwe na skalę przetwarzania, która z kolei powinna być istotnym kryterium branym pod uwagę przy wyrażaniu świadomiej zgody na wykorzystywanie plików cookies. Zatem słuszna jest konkluzja, że informacja o udostępnianiu danych z plików cookies podmiotom trzecim wchodzi w zakres informacji przekazywanych na podstawie art. 5 ust. 3 dyrektywy 2002/58.

Natomiast dyskusyjna jest teza, która zdaje się wynikać z trzeciego punktu sentencji glosowanego wyroku, i która została sformułowana także w opinii rzecznika generalnego ${ }^{26}$, zgodnie z którą informacja udzielana użytkownikowi strony internetowej o wykorzystywaniu plików cookies, gdy dane z nich nie są udostępnianie żadnym podmiotom trzecim, musi również wyraźnie stwierdzać ten fakt ${ }^{27}$. W wyroku, w kontekście tego zagadnienia, TSUE przywołał treść art. 10 dyrektywy 95/46 oraz art. 13 rozporządzenia 2016/679, określających zakres informacji koniecznych do przekazania osobie, od której dane są pozyskiwane. Należy jednak zauważyć, że z treści art. 13 rozporządzania 2016/679 wyraźnie wynika, że informacje o odbiorcach danych osobowych lub o kategoriach odbiorców muszą być podane jedynie wtedy, jeżeli takowi istnieją. Jak wskazuje się w literaturze przedmiotu, nie zawsze wszystkie wymienione w art. 13 ust. 1 kategorie informacji są wymagane, o czym m.in. świadczy warunkowe stwierdzenie zawarte w lit. e wskazanego przepisu ${ }^{28}$. Co za tym idzie, nie wynika z niego wymóg wyraźnego wskazywania, że takowych odbiorców nie ma. Podobnie powinna być też intepretowana treść art. 10 lit. c nieobowiązującej już dyrektywy 95/46. Stąd też zastrzeżenie, że podmioty trzecie nie uzyskują dostępu do danych z plików cookies, można co najwyżej uznać za element uzupełniający opis celu, w jakim dane z cookies są wykorzystywane, a jakim jest podejmowanie określonej formy działań marketingowych na rzecz tych podmiotów.

Przechodząc do tezy o konieczności zawarcia w informacji przekazywanej użytkownikom stron internetowych o okresie funkcjonowania plików cookies, należy ją uznać za w pełni zasadną. Okres wykorzystywania takich plików wprost przekłada się na skalę przetwarzania danych, gdyż wpływa na ilość zbieranych informacji o zachowaniach i preferencjach związanych z przeglądaniem stron internetowych przez konkretnego użytkownika. Zatem informacje te są kluczowe, aby zrozumieć zasadnicze konsekwencje udzielenia zgody. Stąd też, przekazanie informacji co do czasu przechowywania plików cookies, względnie kryteriów wskazywania tego czasu, stanowi jeden z elementów wymogu wyrażenia świadomiej zgody na ich instalowanie. W tym przypadku trafne jest odwołanie się, jak uczynił to TSUE, do treści art. 13 ust. 2 lit. a rozporządzenia 2016/679, który to przepis ma wprost zastosowanie do zbierania danych za

\footnotetext{
$\overline{26}$ Por. pkt 119-121 opinii rzecznika generalnego przedstawionej w dniu 21 marca 2019 r. w sprawie C-673/17, https://eur-lex.europa.eu/legal-content/PL/TXT/?uri=CELEX:62017CC0673 [dostęp: 10.11.2021]; dalej: opinia rzecznika generalnego.

27 W wersji angielskojęzycznej punkt trzeci wyroku brzmi: “Article 5(3) of Directive 2002/58, as amended by Directive 2009/136, must be interpreted as meaning that the information that the service provider must give to a website user includes [...] whether or not [podkr. autora] third parties may have access to those cookies".

28 Zob. P. Fajgielski, Ogólne..., s. 236; por. też K. Wiedemann, The ECJ's Decision...
} 
pomocą technologii typu cookies w przypadku zakwalifikowania ich jako danych osobowych, a który stanowi, że przy pozyskiwaniu danych osobowych - w celu zapewnienia rzetelności i przejrzystości przetwarzania - należy podać informacje dotyczące okresu przechowywania tych danych, a jeżeli nie jest to możliwe, to kryteria ustalania tego okresu ${ }^{29}$.

Powyższe oznacza, że operatorzy witryn internetowych muszą zidentyfikować wszystkie typy plików cookies jakie są wykorzystywane na ich stronach internetowych, a następnie określić czas ich funkcjonowania, a także zidentyfikować podmioty trzecie, które mogą uzyskać dostęp do danych zawartych w tych plikach, aby następnie móc przekazać stosowne informacje użytkownikom.

\section{Literatura}

Barcelo R., Ibraimova A., Yaltaghian E., The Planet49 Decision: Key Takeaways, „The National Law Review"z dnia 2 października 2019 r., https://www.natlawreview.com/article/planet49-decision-key-takeaways [dostęp: 10.11.2021].

Lubasz D., Komentarz do art. 4 pkt 11 [w:] RODO. Ogólne rozporzq̨dzenie o ochronie danych. Komentarz, red. E. Bielak-Jomaa, D. Lubasz, Warszawa 2018.

Litwiński P., Barta P., Kawecki M., Komentarz do art. 4 [w:] Rozporzqdzenie UE w sprawie ochrony osób fizycznych w zwiq̨zku z przetwarzaniem danych osobowych i swobodnym przepływem takich danych. Komentarz, red. P. Litwiński, Warszawa 2018.

Litwiński P., Barta P., Kawecki M., Komentarz do art. 6 [w:] Rozporzq̨dzenie UE w sprawie ochrony osób fizycznych w zwiq̨zku z przetwarzaniem danych osobowych i swobodnym przepływem takich danych. Komentarz, red. P. Litwiński, Warszawa 2018.

Fajgielski P., Ogólne rozporzq̨dzenie o ochronie danych. Ustawa o ochronie danych osobowych. Komentarz, Warszawa 2018.

Wiedemann K., The ECJ's Decision in "Planet49" (Case C-673/17): A Cookie Monster or Much Ado About Nothing? ,"International Review of Intellectual Property and Competition" 2020, nr 51, https://link.springer.com/article/10.1007/s40319-020-00927-w [dostęp: 10.11.2021].

Zanfir-Fortuna G., Planet49 CJEU Judgment brings some 'Cookie Consent' Certainty to Planet Online Tracking, http://www.pdpecho.com [dostęp: 10.11.2021].

29 Z kolei choć w art. 10 dyrektywy 95/46 nie został sformułowany wprost obowiązek wskazania okresu przetwarzania danych, to jednak wymagano podania wszelkich dodatkowych informacji niezbędnych do zapewnienia rzetelnego przetwarzania danych w stosunku do osoby, której dane dotyczą. Tego typu informacją potencjalnie mogła być w określonych sytuacjach również informacja o czasie trwania przetwarzania danych. 


\section{Streszczenie}

\section{Michał Miłosz}

\section{Warunki wyrażenia zgody na użycie plików typu cookies}

W glosie został poddany analizie wyrok Trybunału Sprawiedliwości Unii Europejskiej z dnia 1 października 2019 r. w sprawie C-673/17. Komentowane orzeczenie stanowi pierwszą wypowiedź TSUE w kwestii warunków wyrażenia zgody na użycie tzw. plików cookies w urządzeniach końcowych użytkowników, której wymóg uzyskania wynika w prawie unijnym z art. 5 ust. 3 dyrektywy o prywatności i łączności elektronicznej, uwzględniające przepisy ogólnego rozporządzenia o ochronie danych. Tezy wyrażone w glosowanym wyroku TSUE wyznaczają kierunek wykładni przepisów znajdujących zastosowanie przy instalowaniu plików cookies, i tym samym powinny oddziaływać na praktykę pozyskiwania zgód użytkowników na wykorzystywanie tego typu technologii. W przyszłości na tę praktykę istotny wpływ będzie miało również uchwalenie, a następnie wejście w życie procedowanego obecnie projektu rozporządzenia o prywatności i łączności elektronicznej. Rozporządzenie to będzie zawierać rozbudowaną regulację dotyczącą korzystania z możliwości urządzeń końcowych użytkowników do przetwarzania i przechowywania oraz gromadzenie informacji z tych urządzeń obejmujące również stosowanie plików cookies.

Słowa kluczowe: cookies; zgoda; warunki i forma zgody; wyraźne działanie potwierdzające; zgoda nieskuteczna; RODO.

\section{Summary}

\section{Michał Miłosz}

\section{Consent for the Use of Cookies}

The commented decision of the Court of Justice of the European Union of October $1^{\text {st }}, 2019$, case C-673/17 is the first ruling regarding conditions for giving consent for the use of "cookies" in end-user devices, the requirement of which is provided for in EU law under Article 5 (3) of the Directive on privacy and electronic communications, that takes into consideration the provisions of the General Data Protection Regulation. Theses expressed in the commented decision of the CJUE set the direction for the interpretation of the provisions applicable to the installation of cookies and thus should affect the practice of obtaining users' consent to use this type of technology. In the future, this practice will also be significantly influenced by the adoption and subsequent entry into force of the currently pending draft regulation of the European Parliament and of the Council on the respect for private life and the protection of personal data in electronic communications and repealing Directive 2002/58/EC (Regulation on privacy and electronic communications), which will include an extensive regulation on the use of the capabilities of end-users' devices for processing and storage, as well as collecting information from these devices, including the use of cookies. This commentary contains an analysis of the abovementioned decision of the Court of Justice of the EU.

Keywords: cookies; consent; conditions and form of consent; clear affirmative action; ineffective consent; GDPR. 